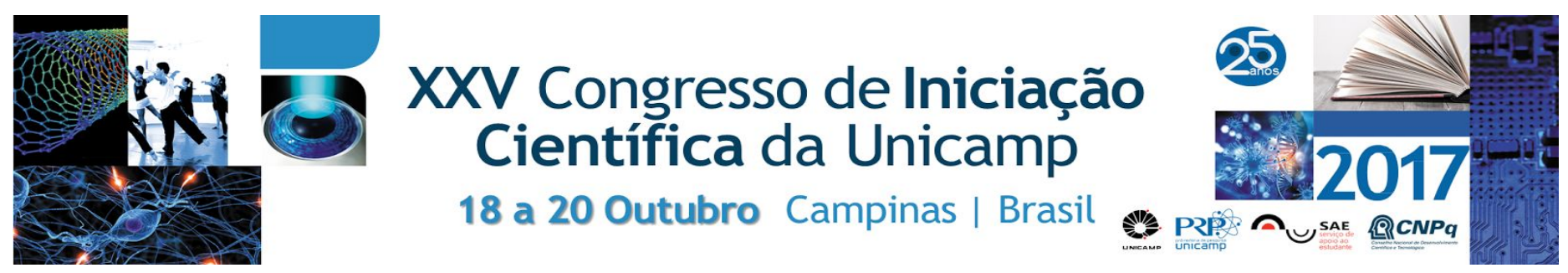

\title{
DESENVOLVIMENTO DE VÍDEOS PEDAGÓGICOS PARA O ENSINO DA FORMA MUSICAL
}

\author{
Adriana N. A. Mendes, Alexandre H. Santos, Anyara M. Agassi*, Leandro A. V. de Almeida, Maécia J. \\ Conceição*, Miguel C. Rubio, Pedro A. Oliveira*, Sandra R. Cielavin.
}

\section{Resumo}

Este projeto propôs o desenvolvimento de vídeos pedagógico-musicais que possam facilitar a aprendizagem da apreciação musical de crianças de 7 a 10 anos. Tomou como ponto de partida as partituras gráficas do pedagogo musical belga Jos Wuytack (1995), chamadas musicogramas, que contribuem para visualizar a estrutura da forma musical de maneira lúdica.

\section{Palavras-chave:}

Musicograma, Educação Musical, Tecnologia.

\section{Introdução}

As ferramentas tecnológicas se tornaram um auxílio em potencial para o ensino-aprendizagem no campo educacional, por sua frequente e intensa presença no cotidiano da sociedade moderna. E, como uma forma de agregar novos recursos tecnológicos ao ensino musical, o projeto realizou a construção de seis vídeos pedagógico-musicais, baseando-se na proposta do pedagogo musical belga Jos Wuytack (1995). Este autor desenvolveu partituras gráficas, chamadas musicogramas, para visualizar a forma musical de maneira lúdica e facilitar a escuta ativa e a apreciação musical. O presente projeto propôs a ampliação da proposta de Wuytack criando vídeos musicais, visando trabalhar a percepção da estrutura musical.

\section{Objetivos específicos:}

a) Estudar procedimentos para utilização dos softwares livres Audacity, MuseScore e Movie Maker para o desenvolvimento dos vídeos;

b) Investigar trechos de peças musicais que pudessem ser transformados em vídeos, favorecendo a aquisição do conceito de forma em música e o conhecimento de elementos básicos do som para crianças de 7 a 10 anos; c)Desenvolver seis vídeos pedagógico-musicais;

d)Publicar artigos científicos sobre o assunto.

\section{Resultados e Discussão}

Foram desenvolvidos seis vídeos pedagógico-musicais e os três bolsistas participaram ativamente de todo o processo, compreendendo os procedimentos para a realização de um projeto de pesquisa na universidade. Trouxeram contribuições pessoais para a confecção dos musicogramas escolhendo músicas, confeccionando imagens e participando da gravação das músicas.

Em relação ao conteúdo do material elaborado, foram abordados nos musicogramas distintos elementos básicos do som, como: timbre, duração, intensidade e altura; de forma que tais elementos sejam mais facilmente assimilados pelas crianças e jovens que entrem em contato com os musicogramas.
Figura 1. Três Indiozinhos - aborda altura

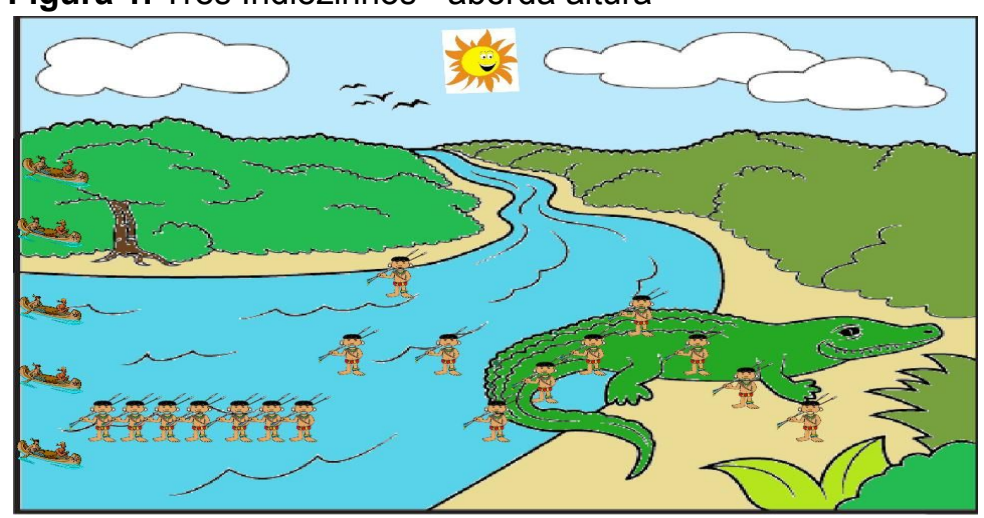

Figura 2. O Trenzinho do Caipira- aborda duração

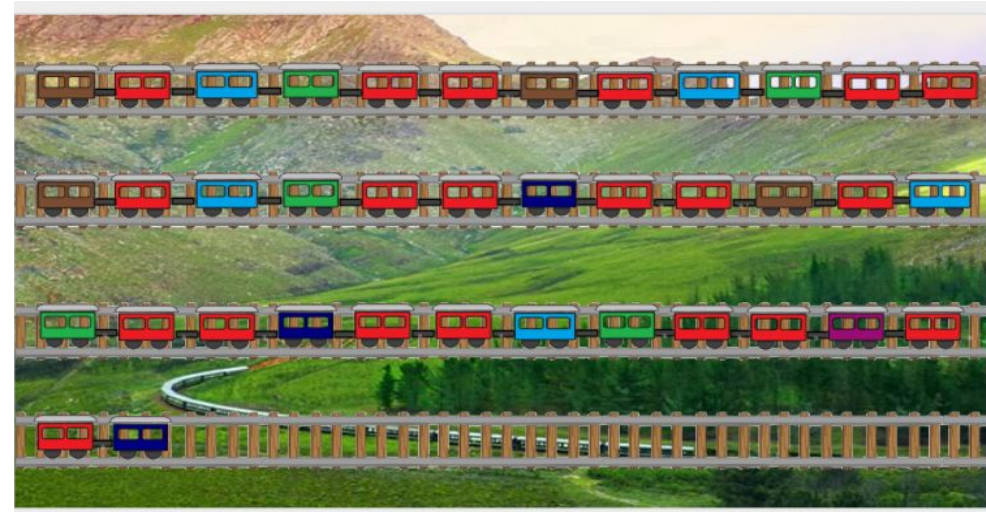

\section{Conclusões}

Os musicogramas contribuem visualmente para a ampliação da compreensão auditiva dos elementos musicais básicos. $\mathrm{E}$ os vídeos confeccionados poderão ser utilizados com crianças e adolescentes em uma próxima etapa do projeto.

\section{Agradecimentos}

Agradecemos à Pró-Reitoria de Pesquisa da Unicamp e ao CNPQ pelo apoio nesse projeto.

WUYTACK, Jos; PALHEIROS, Graça Boal. Audição Musical activa. Livro do professor. Porto, Portugal: Associação Wuytack de Pedagogia Musical, 1995 